Article

\title{
The Impact of Late Holocene Flood Management on the Central Po Plain (Northern Italy)
}

\author{
Filippo Brandolini *(i) and Mauro Cremaschi \\ Earth Sciences Department “Ardito Desio"-Università degli Studi di Milano, Milan 20133, Italy; \\ mauro.cremaschi@unimi.it \\ * Correspondence: fibrandolini@gmail.com; Tel.: +39-025-031-5525
}

Received: 22 September 2018; Accepted: 28 October 2018; Published: 31 October 2018

check for updates

\begin{abstract}
Fluvial environments have always played a crucial role in human history. The necessity of fertile land and fresh water for agriculture has led populations to settle in floodplains more frequently than in other environments. Floodplains are complex human-water systems in which the mutual interaction between anthropogenic activities and environment affected the landscape development. In this paper, we analyzed the evolution of the Central Po Plain (Italy) during the Medieval period through a multi-proxy record of geomorphological, archaeological and historical data. The collapse of the Western Roman Empire (5th century AD) coincided with a progressive waterlogging of large floodplain areas. The results obtained by this research shed new light on the consequences that Post-Roman land and water management activities had on landscape evolution. In particular, the exploitation of fluvial sediments through flood management practices had the effect of reclaiming the swamps, but also altered the natural geomorphological development of the area. Even so, the Medieval human activities were more in equilibrium with the natural system than with the later Renaissance large-scale land reclamation works that profoundly modified the landscape turning the wetland environment into the arable land visible today. The analysis of fluvial palaeoenvironments and their relation with past human activities can provide valuable indications for planning more sustainable urbanized alluvial landscapes in future.
\end{abstract}

Keywords: flood management; wetland; land use change; landscape transformation; resilience; late Holocene; medieval age

\section{Introduction}

Floodplains are preferred areas for human settlements due to their suitability for agriculture activities, and many studies substantiate the interpretation of floodplains as complex human-water systems [1-3]. Indeed, water and land management activities have altered fluvial landscape development to create cultivable land, while simultaneously protecting communities from the risk of flooding events, which are still the most common natural disasters worldwide [4,5].

In Europe, the reciprocal interaction between fluvial environments and human activities has been documented since the Neolithic [6,7], when fluvial landscapes were first altered for agriculture purposes. Today, floodplains are densely cultivated, and the modern European countryside is principally derived from the human landscape modification that occurred in medieval times.

In the Early Medieval Age (6th-9th centuries AD) few cases of large-scale anthropogenic land and water management activities are known (es. Fossa Carolina [8,9]) compared to later centuries. Even though there are some differences between the northern and central Europe and the Mediterranean region, the anthropogenic reshaping of the natural environment was principally a result of overall population growth. Between the 10th and the 13th centuries AD, concurrent with the Medieval Warm Period climate phase [10-12], the European population grew substantially, 
almost tripling (in Northern and Central Italy, the urban population doubled), and increasing the demand for cultivated lands [13-16]. Cereals became a more significant constituent in the average diet and in the agrarian regime compared to the centuries before, leading populations to reconfigure the medieval natural landscape for agricultural purposes. In creating new land for cultivation and settlement, the European communities triggered a massive landscape transformation through woodland clearance, arable intensification, the development of irrigation systems and the drainage of wetlands. Land reclamations works profoundly modified many European regions: the peatlands in the Netherlands [17-20]; the coastal marshlands in the UK [13,21] and in North Frisia (Germany) [22] and the alluvial wetlands in the Po Valley (Northern Italy) (Figure 1) [17]. In the latter, specifically the Emilia-Romagna region (Central Po Plain), the earliest evidence of attempts to clear the forests and drain the wetlands is mentioned in historical documents from the late 8th century [23,24], but only from the 10th to the 13th centuries were land and water management activities actually carried out widely. The proponents of those activities were mostly monasteries [25-27] such as Nonantola, Santa Giulia, Mirandola, San Benedetto in Polirone [28], and also local lords who contributed to colonizing new farmland by forcing rural people to live into new fortified settlements (incastellamento process [29-31]).

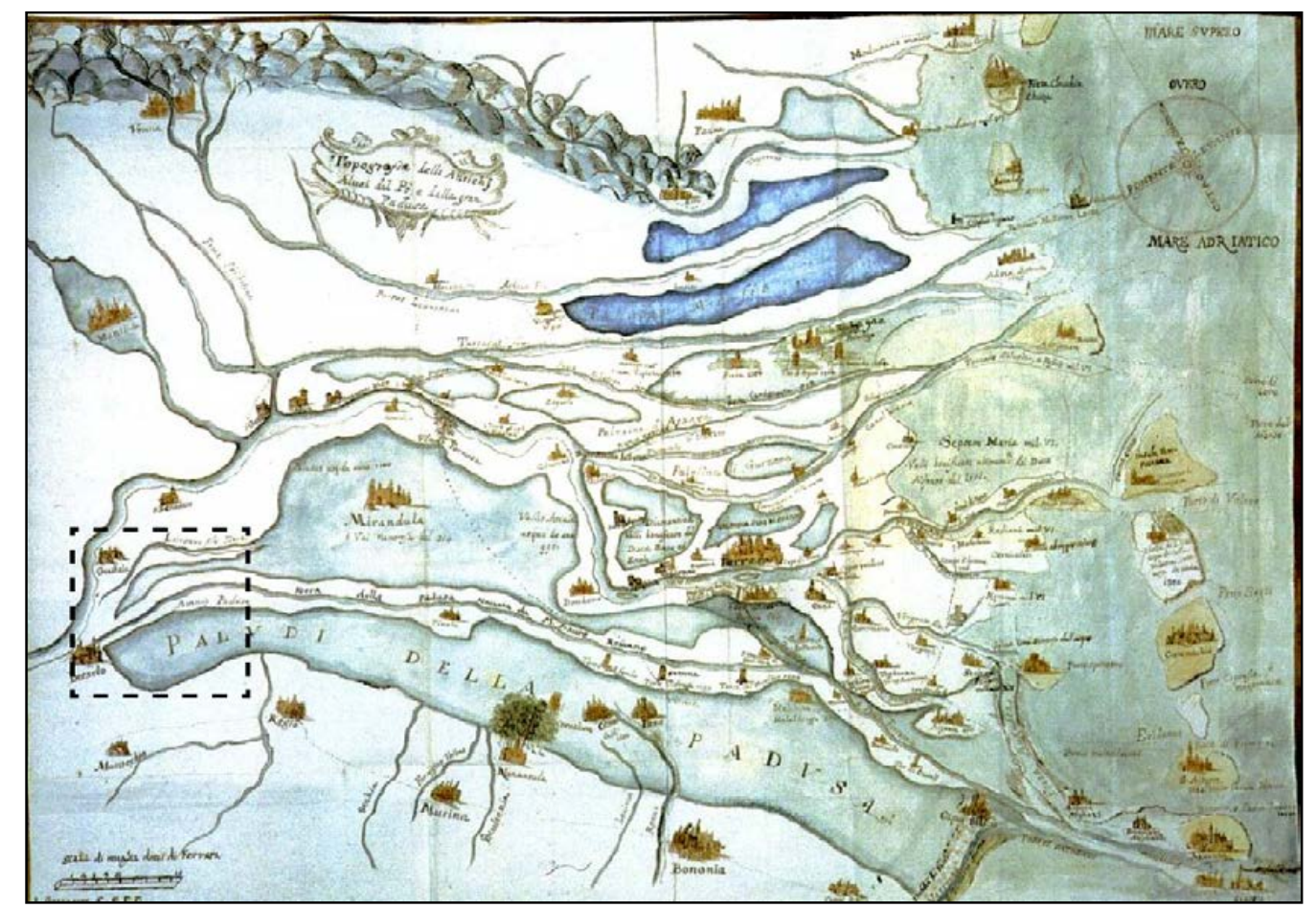

Figure 1. The wetlands in the Po Plain before the Renaissance land reclamation works, 1570 AD. Library of the Univerisità degli Studi di Bologna [32]. The dashed line indicates the research area.

According to historical maps and documents the land reclamation of the Central Po Plain reached its peak during the Renaissance (15th-16th centuries AD) [33] and continued in the Modern Age (17th-18th centuries AD), with the last marsh areas only being reclaimed in the 20th century AD: channels and drainage system are still active and allow the Po Valley to be drained and be cultivatable [34].

During the last two centuries, the height of the Po river embankments have been raised significantly to protect urban areas, and the river has become increasingly controlled, but the debate around future sustainable flood management activities is ongoing. In particular, with steadily increasing embankment heights, the potential flood depth increases, which in turn increases the flood damage if a failure occurs. The heightening of embankments, indeed, represents a component of the so-called 'levee effect' [1,35]; flood defenses actually increase overall vulnerability, as protection from 
regular flooding reduces perceptions of risk and encourages inappropriate development in alluvial floodplains [3]. A possible correct strategy to reduce the flood hazard when considering very large or extreme events consists of exploiting areas outside of the main embankments with the 'Room-for-River' approach $[36,37]$. In the case of the Po River, for example, the main embankments are already very tall along large sections of the river, and their further raising is not environmentally sustainable [2].

The environmental evolution of the Central Po Plain and its relationship to human activities has been thoroughly studied for prehistoric periods and the Roman Era [38-44]; however, these human-environment interactions in subsequent centuries are less apparent. The post-Roman Era represents a crucial moment in the Late Holocene development of the Po Plain when a large portion of the well-organized Roman countryside turned into vast alluvial wetlands [45]; the Roman drainage system collapsed, and the inhabitants had to deal with living in a waterlogged environment.

This study aims to detect and disentangle the mutual interaction between anthropogenic activities and environmental changes that occurred in the post-Roman Era integrating geomorphological analysis with historical and archaeological data. The application of a multidisciplinary approach enables the quantification of the impact of human activities on the development of the wetland environment in Central Po Plain during the Middle Ages.

\section{Study Area: Geomorphological and Historical Contexts}

The research area is located in the Central Po Valley, south of the Po River, a few kilometers north of the Tuscan-Emilian Apennine margin, between the cities of Parma and Reggio Emilia (Figure 2). Since the Pleistocene, the Apennine watercourses shaped the landscape developing alluvial megafans with their sediments (Figure 3). In the study area, the distal parts of Holocene alluvial fans are characterized by a telescopic shape, a result of subsequent aggradation (Aggradation indicates the increase in land elevation, typically in a river system, due to the deposition of sediment.) - entrenchment phases due to the alternation of glacial-interglacial periods; each aggradational cycle causes an incision on the top of the previous fan, while a new fan prograded in a more distal position [41]. In the study area, the alluvial ridges of the Enza, Crostolo and Tresinaro, emerging from the flat floodplain, flank depression areas known in fluvial geomorphology as backswamps, which are characterized by deposits of fine silts and clays deposited after flood events [46].

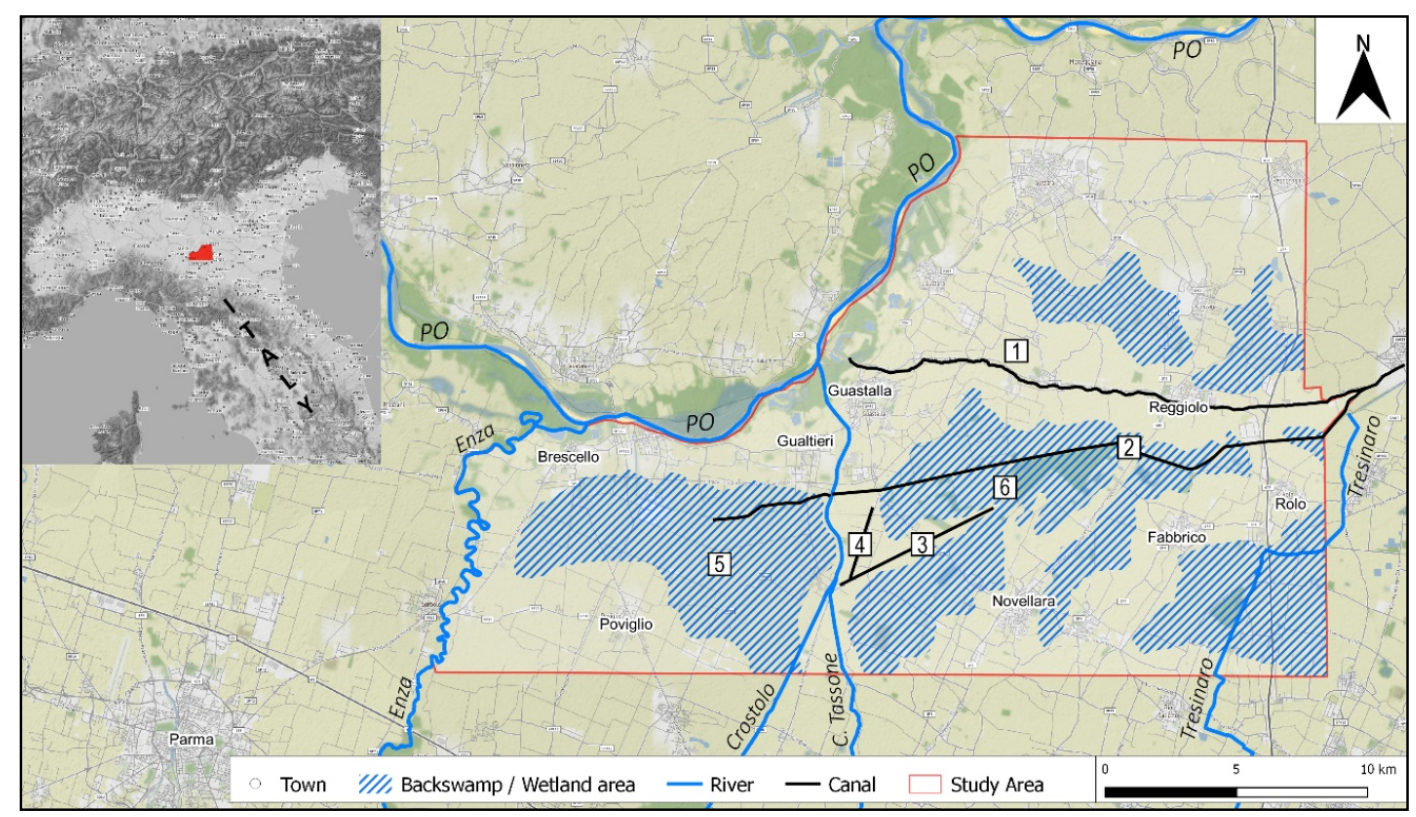

Figure 2. Location of the study area. 1-Tagliata Canal; 2-Parmigiana Canal; 3-Crustulus Vetus; 4-Camporainero area; 5-Valle di Gualtieri backswamp; 6-Valle di Novellara backswamp. 


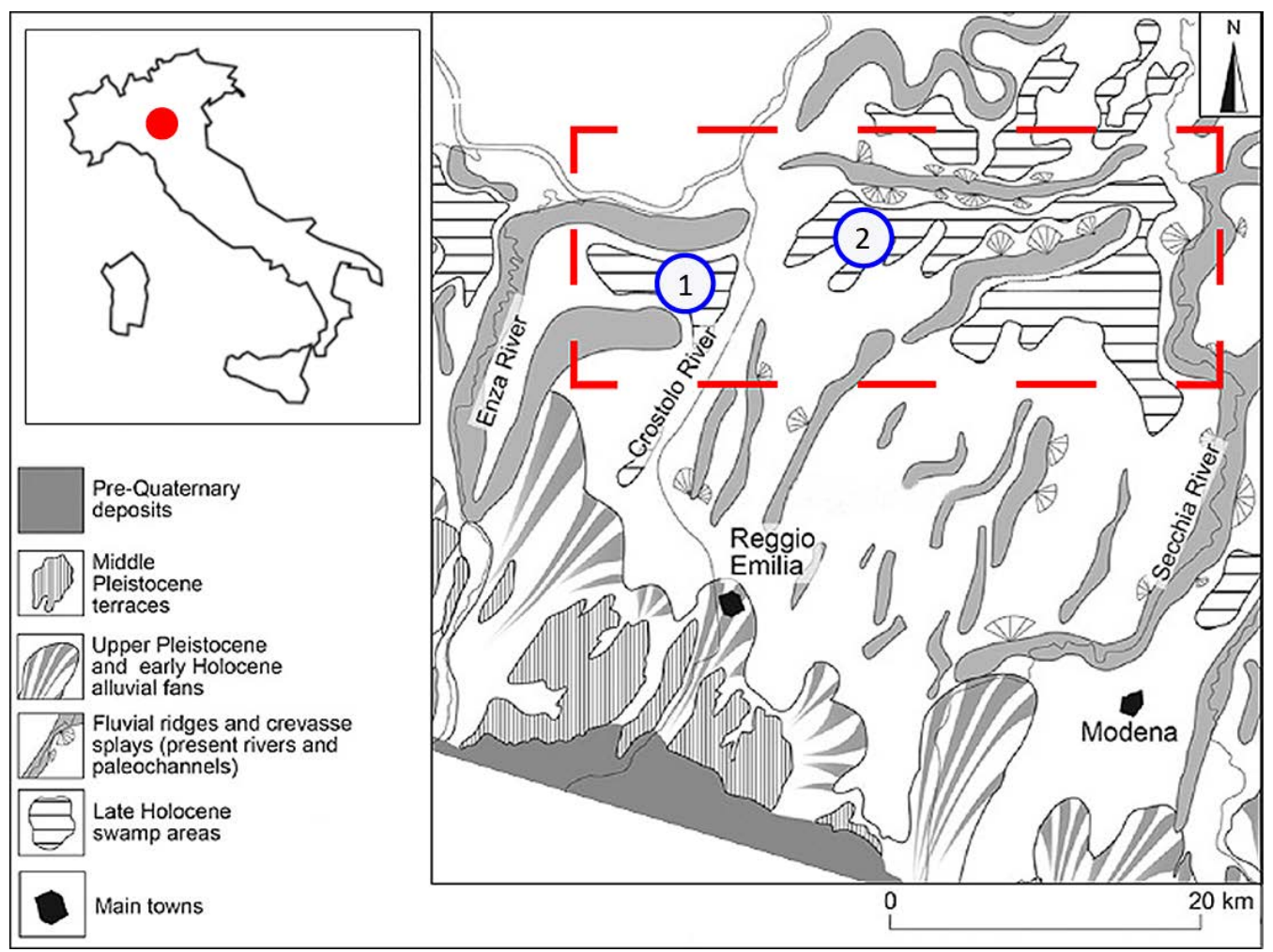

Figure 3. Schematic geomorphic map of the Po plain in the Emilia region (adapted from [47-49]). The red dashed line highlights the study area: 1-Valle di Gualtieri; 2 -Valle di Novellara.

The landscape evolution of this portion of the Central Po Plain has a long-standing connection with human activities. Protohistoric human-environmental interactions have been widely investigated $[39-41,49,50]$ but the first historical large-scale land and water management project in the study area is dated to the 2nd century BC. At that time, the Romans colonized the Po Valley and profoundly modified the natural landscape dividing the cultivated land into square fields by a regular grid of roads and ditches [38,51,52]. After the collapse of the Roman Empire (5th century AD), lack of maintenance of the irrigation systems [24] associated with a cooling climate phase (i.e., the so-called Migration Period or the Dark Age Cold Period; $[10,11,53]$ led to the progressive waterlogging of the Po Valley and the natural depressions on the right side of the Po River turned in two vast swamp basins known as Valle di Gualtieri and Valle di Novellara (Figure 3). In particular, the Roman water management augmented the Holocene sedimentary process of Apennine watercourse with consequent aggradation of the river beds. Therefore, in the post-Roman period, channel diversions affected the southern tributaries of the Po River, especially the Crostolo Creek that flowed in the floodplain depressions: vast areas became marshy and Roman sites, and centuriation tracks were often buried under fluvial and palustrine deposits [42,45]. The waterlogging process of the area continued until the 10th century AD influencing human sustenance and settling practices [25,54]. According to historical-archaeological data the wetlands were exploited for fishing as well as for water transport by boat $[55,56]$ while the early medieval sites were settled on the fluvial ridges, in topographically higher and strategic positions relative to the surrounding swampy meadows $[24,30,31,57]$. In the study area, channelization and reclamation works started in the 10th century AD [58-62] and increased between the 12th and the 13th centuries $[25,26,63]$, promoted both by monasteries $[28,64]$ and by private landowners [65].

Large-scale ground reclamation began during the Renaissance and is known in the literature as Bonifica Bentivoglio, after the name of its promoter, Cornelio Bentivoglio, Lord of Guastalla. The Bonifica Bentivoglio drainage system reclaimed a significant portion of the swampy meadows and was renovated and updated many times in the Modern Age; between 17th and 19th centuries, many homesteads were settled in the reclaimed farmland. The land reclamation of this portion of the 
Central Po Plain continued for centuries after the Renaissance and was completed only in the 20th century $\mathrm{AD}[33,34,66]$, resulting in an entirely artificial landscape.

\section{Materials and Methods}

This study has been performed using a multi-proxy record to analyze the Late Holocene transformations of the Central Po Plain: geomorphological tools were combined with archaeological data and historical documents.

The geomorphological literature on the Central Po Valley $[45,47,48,67,68]$ constituted a useful starting point in association with a 1-m DEM (produced from high-resolution LiDAR) provided by the national geodatabase [69]. The elevation checkpoints (m.a.s.l.) provided by the regional geodatabase [70] have been elaborated with the software QGIS (2.18) to draw contour lines with an equidistance of $0.5 \mathrm{~m}$ and to create the final Digital Terrain Model (DTM) of the research area (Figure 4). Moreover, to enable the interpretation of the geomorphological features detected by the DTM, a 3D model has been created by the software QGIS plugin Qgis2threejs exaggerating the DTM Z-value $\times 50$.

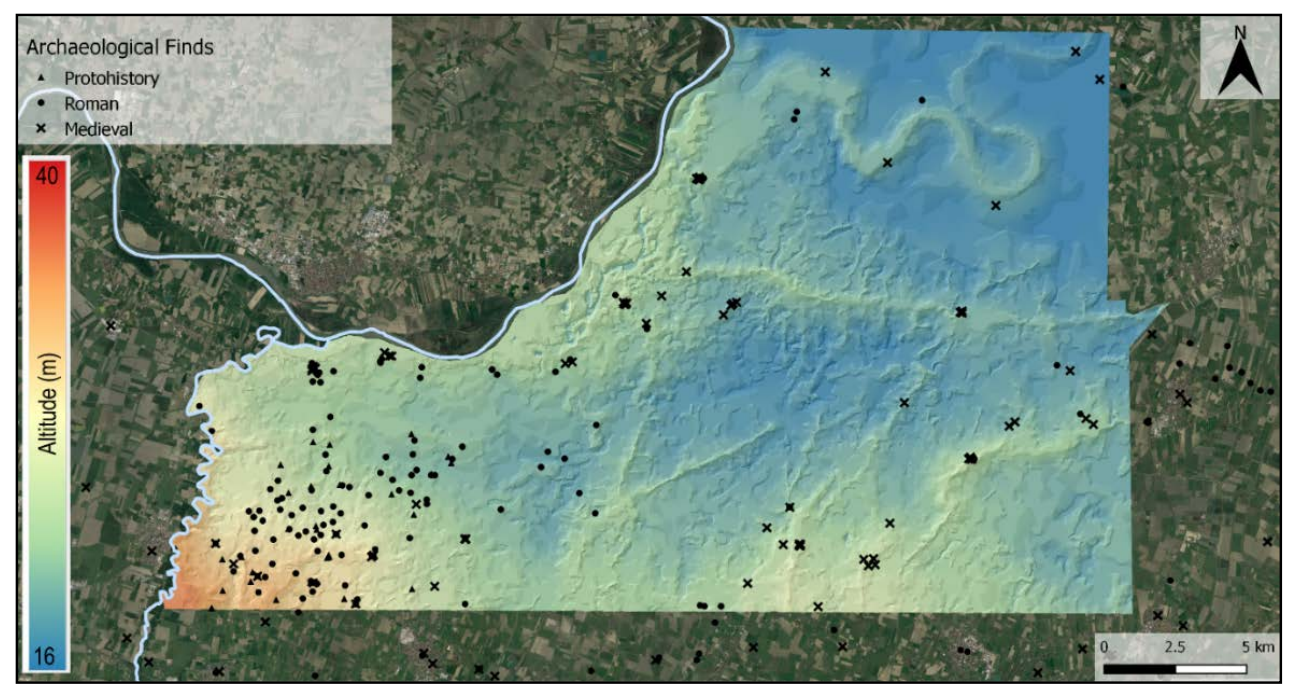

Figure 4. Digital Terrain Model elaborated with software QGIS implemented with archaeological records. In the north of the mapped area, the meandering geomorphological feature corresponds to the so-called Po Morto or Dead Po, active in Roman Times.

The regional soil map has been applied to the 3D model to detect the maximum extension of the medieval swamps before the Renaissance land reclamation works, and our interpretation is based on the different types of sediments and their concentrations.

The landforms detected have been dated and contextualized according to archaeological and historical records. The archaeological evidence (sites and materials) has been compiled from various records [48,51,62,71,72], a regional web database [73] and terrain surveys. The 18th and 19th century transcriptions of medieval accounts and parchments [58-60,74] served as an advantageous starting point in the analysis of the historical documents along with the 20th-century editions of medieval documents kept at the Parma and Reggio Emilia National Historical Archives [75-77]. Additional information has been collected at the Novellara Historical Archives, including from the archive fund "Cavamenti Acque (1495-1931)" [78]. All of the archaeological (sites and materials) and historical (place names) data have been organized according to epochs in different layers using QGIS software.

\section{Results and Discussion}

The multidisciplinary approach allowed us to shed new light on anthropogenic activities related to land and water management in the post-Roman landscape. In medieval times, humans exploited 
the palustrine environment (Palustrine environment refers to any (no-tidal) inland wetland. Wetlands within this category include inland marshes, swamps and floodplains.) as a resource, until the demand for more arable land led to land reclamation. The impact of medieval human activities on the landscape resulted in altering the natural shape of the area through the development of anthropogenic geomorphological features.

The results will be discussed in three categories related to the backswamps limits, the Tagliata Canal and the Crostolo River, respectively.

\subsection{Backswamps Limits}

As mentioned above, the collapse of the Roman Empire was associated with a period of climatic instability [79] that led to the progressive waterlogging of the Po Valley; frequent flood events have been reported in historical chronicles between 6th and 7th centuries AD [80]. In the study area, the floodplain on the right side of the Po River turned in two vast backswamps; the Valle di Gualtieri and the Valle di Novellara (hereafter, the two Valli). The backswamps are the lower area of floodplains, poorly drained, and where only finer material accumulates during a flooding event [81]. This palustrine environment served as a resource for silvopastoral practice, especially in the Early Medieval period. Historical documents $[75,76,82]$ report that local communities exploited the Valli swamps for fishing and transport by boat; in sale-purchase agreements "piscationes, paludes et lacus" (i.e., fisheries, marshes, ponds) were traded, as well as any other goods such as fields or vineyards. Despite this central role in the economy of the period, in historical documents, there is no precise information about the swamps' geographical limits, perhaps because their physical boundaries constantly fluctuated during the Middle Ages climatic variations.

To determine accurate limits for the two Valli, a 3D model of the area (Figure 5) has been extrapolated exaggerating the DTM elevation attribute $\times 50$. Superimposing the regional soil map (Geoportale Emilia Romagna) on the 3D model shows a relationship between the concentration of clayey and silt-clayey soils and the lowest areas detected in the DTM (Figure 6). These data are entirely compatible with the geomorphological definition of back swamps as low flat standing areas where fine sediments settle after a flood event. According to the model rendered, the maximum extension of the Valle di Gualtieri and Valle di Novellara covered an area of $\approx 250 \mathrm{Km}^{2}$ (Figure 7). The medieval archaeological records $[30,31,51,52]$ seems to further confirm the swamps limits as determined by the 3D model; all of the archaeological finds and the historical toponyms [59,75] are distributed surrounding the two Valli. The wetlands had an economic potential, but one that was far below the full agricultural potential of the same land after the reclamation that occurred starting the 10th century AD. Further palaeoecological and geoarchaeological analyses will be useful to provide more information about the character of the wetland environment in the study area.

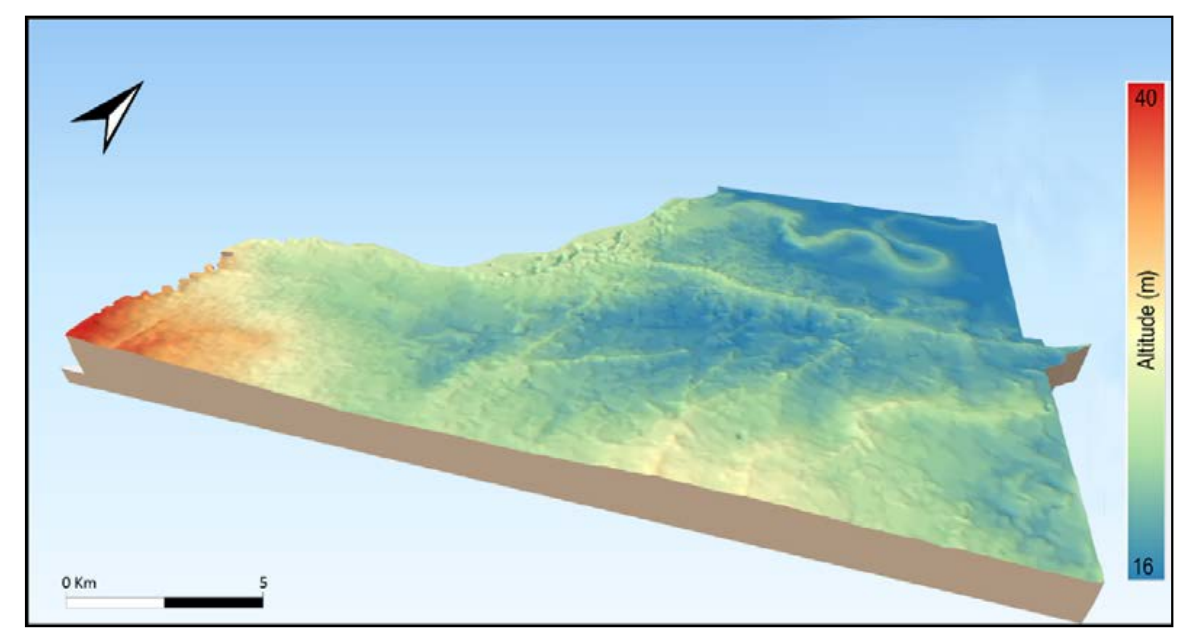

Figure 5. The 3D model: altitude checkpoints attribute $\times 50$. 


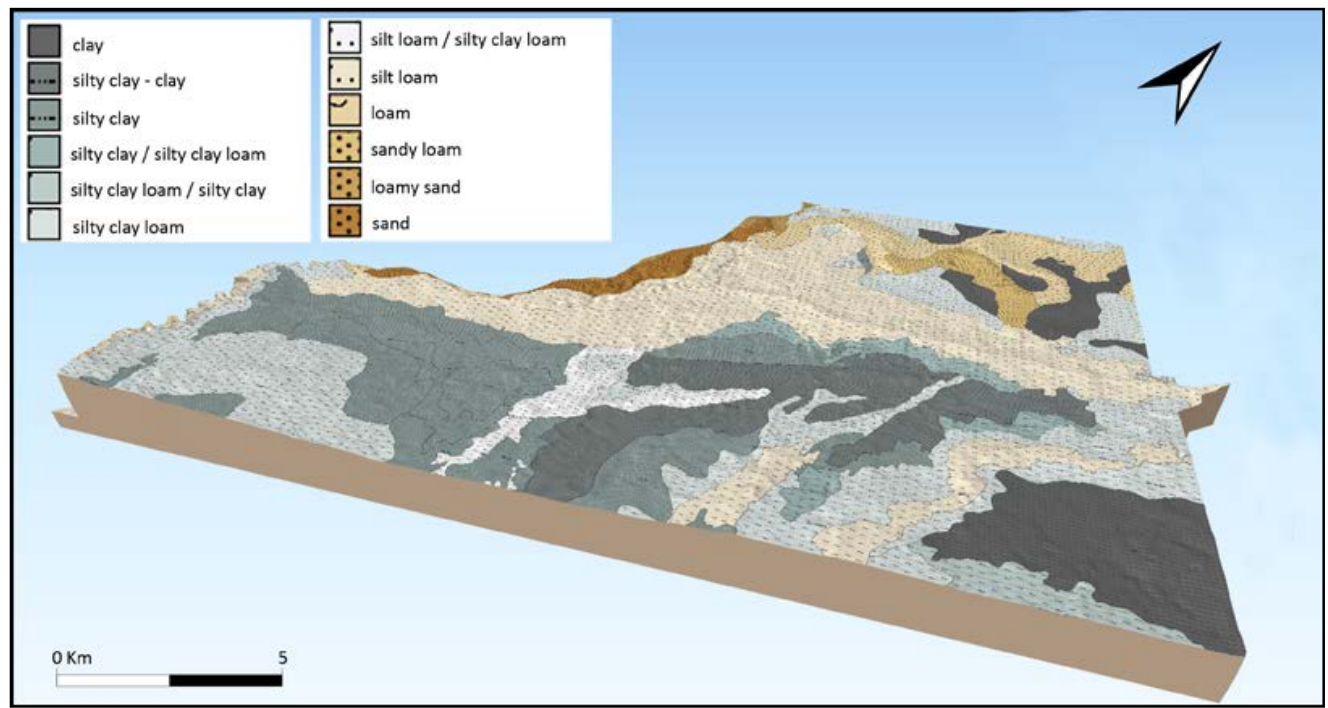

Figure 6. Application of the soil map [70] to the 3D model. Grey and Dark-Grey areas correspond to fine sediments settled after flood events.

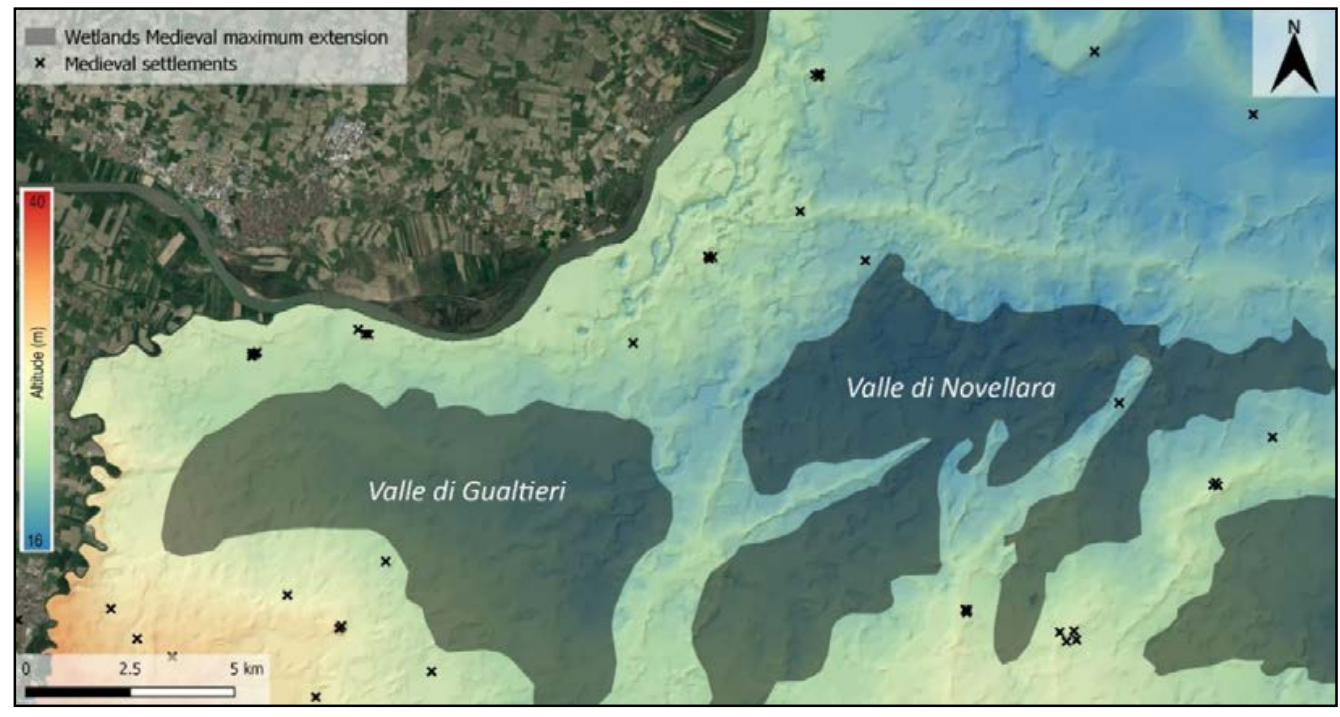

Figure 7. Maximum extension of wetlands before the Renaissance large-scale land reclamation project.

\subsection{Tagliata Canal}

The most valuable data about anthropogenic activities in the medieval environment concern the northern limit of the Valle di Novellara. According to the DTM, this backswamp is delimited in the north by the ridge of the so-called Tagliata Canal. In scientific literature $[41,43,47,67,68]$ the Tagliata Canal is considered a Proto-historic Po ridge characterized by crevasse splays on both sides (Figure 8); however, geomorphological, archaeological, and historical data suggest a new interpretation. First, the distribution of archaeological evidence in the study area shows an absence of Bronze Age and Roman Era findings (both sites and materials) (Figure 9). It is likely that the subsequent reworking of the fluvial landscape has obscured pre-medieval archaeological evidence. The 13th-century chronicler Fra Salimbene de Adam reported that, between the two towns of Guastalla and Reggiolo, there used to be a waterlogged area that was drained only after the excavation of the Tagliata Canal (Table 1, I). Thus, the accretion of Tagliata Canal ridge occurred after the collapse of the Roman Empire, not before. 


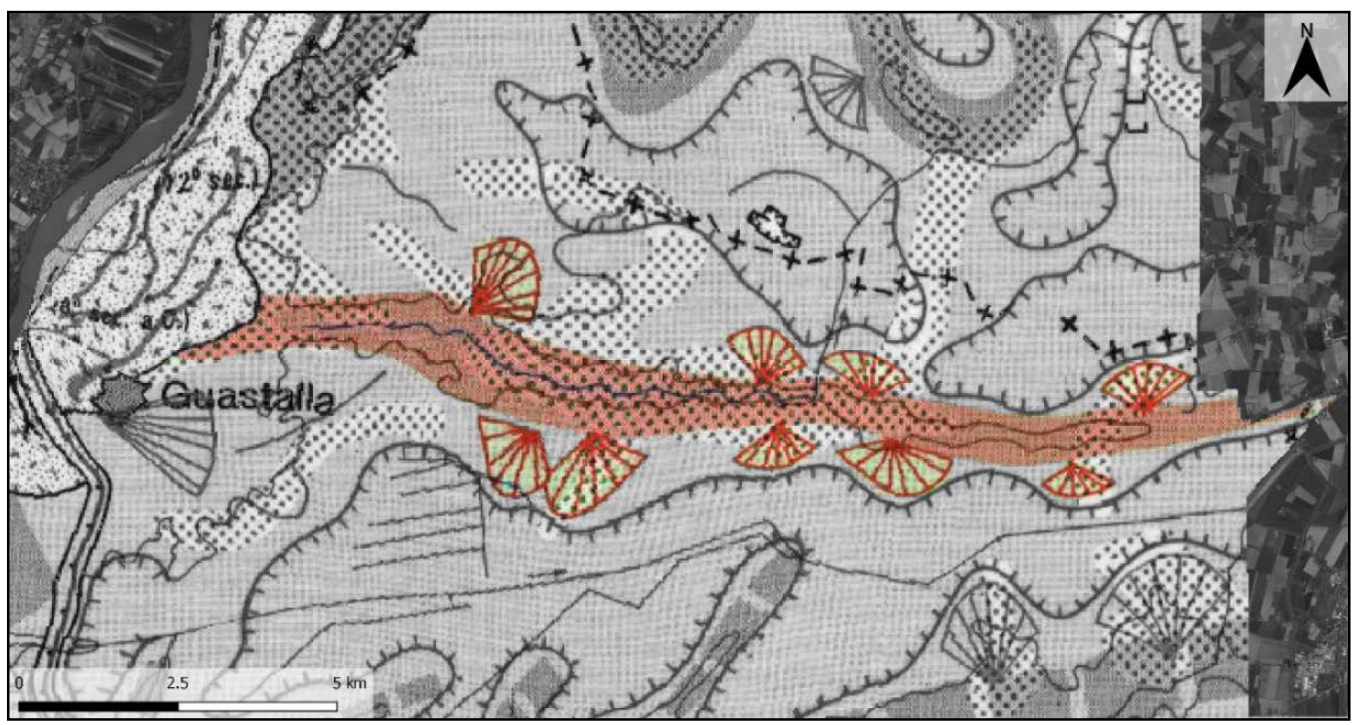

Figure 8. The Tagliata Canal in the geomorphological map of the Po Plain edited in 1997 [47]. The Tagliata Canal is considered a Proto-historic Po ridge characterized by crevasse splays on both sides.

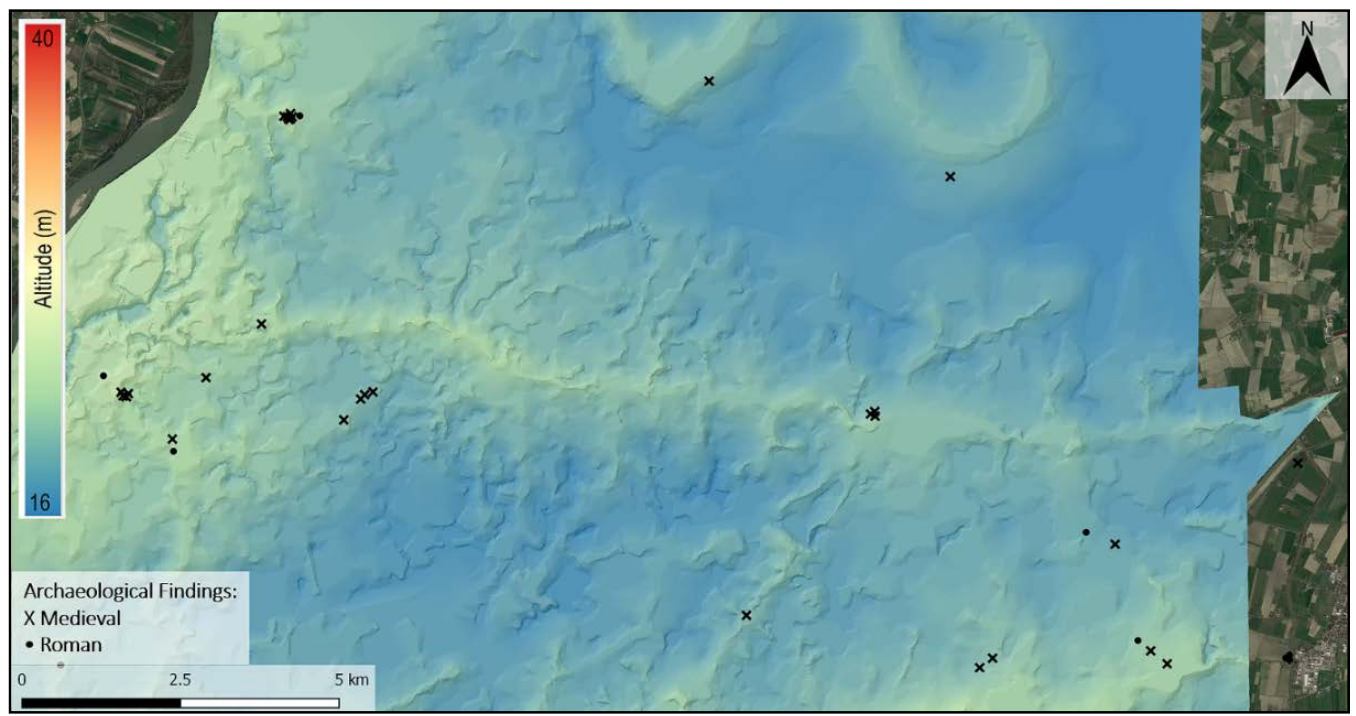

Figure 9. The distribution of archaeological sites and materials in the study area shows an absence of Bronze Age and Roman Era findings suggesting that the Tagliata Canal ridge developed in medieval times.

Moreover, historical documents $[59,60,74]$ report that the Tagliata Canal was artificially excavated in 1218 for commercial purposes. The new canal enabled a bypass of the Po River from Guastalla to Reggiolo for the city of Cremona in order to avoid paying commercial fees to the city of Mantova, which controlled the local waterways.

The medieval chroniclers, also, report that the construction of Tagliata Canal had negative implications for the environment with frequent floods in the surrounding farmland. In 1269, for example, the chronicler Fra Salimbene reported a severe flood event (Table 1, II) and many other floods occurred between the 13th and 14th centuries AD [60].

The geomorphological evidence of those medieval floods should be attested via the crevasse splay detected near Fangaia and Villarotta, two villages that were settled on the Tagliata ridge after the canal excavation. Nevertheless, these two villages' place names are reminiscent of flooding vocabulary (i.e., Fangaia from "Fango" $\rightarrow$ mud, refers to alluvial sediments; or Villarotta from Rotta $\rightarrow$ breach levee, refers to a crevasse splay event) (Figure 10). 
Table 1. Historical quotes about the environmental transformation of the research area in medieval times.

\begin{tabular}{|c|c|c|c|c|}
\hline No. & Object & Chronicler & Medieval Italian & English Translation \\
\hline I & $\begin{array}{l}\text { Tagliata } \\
\text { Canal }\end{array}$ & $\begin{array}{l}\text { Fra Salimbene de } \\
\text { Adam } \\
\text { (13th century AD) } \\
{[60] \text { p. } 89}\end{array}$ & $\begin{array}{l}\text { "Tra Guastalla e Reggiolo era una stesa di terreno } \\
\text { paludoso le cui acque incanalate nel detto cavo e } \\
\text { asciugato il territorio, si conquistarono alla } \\
\text { coltivazione ubertosissime campagne [ . . ]" }\end{array}$ & $\begin{array}{l}\text { "Between Guastalla and Reggiolo there used to } \\
\text { be a waterlogged area whose waters were } \\
\text { channelled in the canal (Tagliata): the land was } \\
\text { drained and turned into very fertile farmland". }\end{array}$ \\
\hline II & $\begin{array}{l}\text { Tagliata } \\
\text { Canal }\end{array}$ & $\begin{array}{l}\text { Fra Salimbene de } \\
\text { Adam } \\
\text { (13th century AD) } \\
\text { [60] p. } 93\end{array}$ & $\begin{array}{l}\text { "Questa Tagliata impaludò larga zona di terreni, } \\
\text { distrusse e sommerse molte ville, e dove prima di } \\
\text { aveva abbondanza di frumento e di vino, ora si ha } \\
\text { copia di pesci di diverse specie" }\end{array}$ & $\begin{array}{l}\text { "The Tagliata canal flooded a wide area, razed } \\
\text { many houses, and in place of wheat fields and } \\
\text { vineyards now there is an abundance of fishes } \\
\text { of different species". }\end{array}$ \\
\hline III & $\begin{array}{l}\text { Tagliata } \\
\text { Canal }\end{array}$ & $\begin{array}{l}\text { Ireneo Affò } \\
\text { (18th century AD) } \\
\text { [58] Vol. 8, p. } 233\end{array}$ & $\begin{array}{l}\text { "I ... I La comunità da tempo memorabile aveva } \\
\text { diritto di rompere gli argini quando menavano } \\
\text { acque torbide perché spandere si potessero nelle valli. } \\
\text { E molti uomini testificarono il mirabile effetto che ne } \\
\text { era seguito, accennando de campi allora coltivabili } \\
\text { nel luogo dei quali a loro memoria solevano i } \\
\text { pescatori andare con le barche [... .]" }\end{array}$ & $\begin{array}{l}\text { "Since time immemorial, the community } \\
\text { (of Guastalla) was allowed to breach the levees } \\
\text { when the watercourses carried turbid water to } \\
\text { spread them in the wetlands. Many people } \\
\text { testified to the admirable effect that followed, } \\
\text { and they said that now cultivable fields } \\
\text { replaced places in which fishermen were used } \\
\text { to going by boat" }\end{array}$ \\
\hline
\end{tabular}

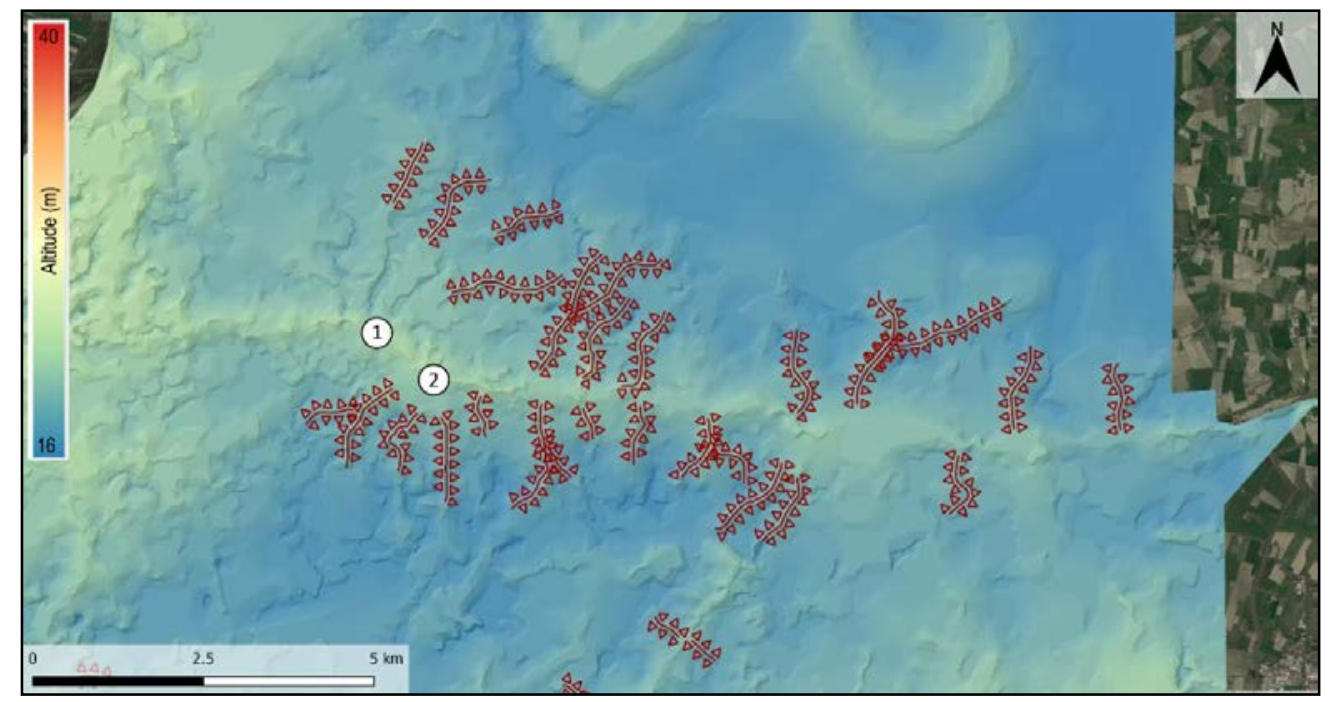

Figure 10. Geomorphological analysis of the Tagliata Canal ridge: crevasse splays and land-fill ridges. 1-Villarotta; 2-Fangaia.

The geomorphological analyses provide more nuanced information about the shape of the Tagliata Canal. In the DTM, the morphology of Tagliata Canal ridge seems to be more complicated than what is represented in the geomorphological map of The Po Plain [47]. The crevasse splays show unusual elongated small ridges not compatible with natural fluvial crevasse splays. Information in the historical documents provide a possible explanation for their genesis: the chronicler Affo' [58] reports that since the 13th century $\mathrm{AD}$, people of Guastalla were allowed to breach the artificial levees of rivers and canals in a situation of high, muddy discharge (Table 1, III). This practice had the effect of infilling the swamps with sediments, thus creating new farmland, and the elongated shape of the unusual landforms could be the results of those practices. Although such flood management practices have never been reported in geomorphological and geoarchaeological studies on Central Po Plain so far, these few cases noted in the literature could support our interpretation. Recently, medieval archaeological excavations in the Ligurian Apennine reported that watercourse sediments and colluvial deposits had been exploited to reclaim palustrine environments [83,84]. In the medieval sites of Mogge di Ertola (Genova-Italy) and Torrio (Piacenza-Italy), marshes were turned into terraces by applying a technique called "colmata 
di monte": the sediments carried by mountain watercourse were managed to fill palustrine areas and create new arable land and pasture [85]. The process of breaching levees described in Affo' [58], is very similar to the "colmata di monte" reported in the Apennine archaeological sites. The elongated shape of the Canal Tagliata crevasse splays are the results of medieval flood management practices intended to reclaim the backswamp of Valle di Novellara; we decided to define these unique anthropogenic geomorphological features as Land-Fill Ridge (or dosso per colmata) (Figure 10).

Additionally, the land-fill ridge detected in this study serves as an interesting comparison with the warping practices that occurred in England in the 18th century AD. Research in Humberland Levels [86,87] and the lower Trent Valley [88] wetlands has highlighted the considerable degree to which a combination of natural alluviation and anthropogenic warping deposits have concealed palaeoland surfaces and the archaeological record of the two regions. The warping practices have been carried out since the 18th century AD and consist of the artificial diversion of fluvial sediments in a wetlands area. Warping was conducted mainly to fertilize large areas: where the peats were too acidic, warp deposits served to mask unproductive wetlands with a light, well-drained silty or silty-clay soil. Anthropogenic warping practices also aimed to reduce the impact of the spring tides which had left large areas of the region waterlogged for most of the year. The land to be warped was first enclosed by embankments, then a regular network of small canals (often still visible in aerial images as crop marks) ensured the rapid and even distribution of flood water throughout the compartment, creating a uniform deposit $[86,88]$. Even though the process that generates land-fill ridges and warps is quite similar (i.e., the artificial exploitation of substantial silt and clay load carried in suspension by canals and rivers), in the research area, there is no historical or geoarchaeological evidence of both embankments and fertilizing practices in alluvial wetlands.

\subsection{Crostolo River}

In the post-Roman era, the Crostolo River diversion channel caused the waterlogging of a large area of the Roman countryside; the river flowed into the Valli backswamps turning the farmland into a palustrine environment (Figure 11). In medieval times, human enterprise on the Crostolo River was concentrated in the portion of the watercourse that crossed the city of Reggio Emilia. Here, to prevent flooding hazards, the river was artificially diverted outside the city walls [49].

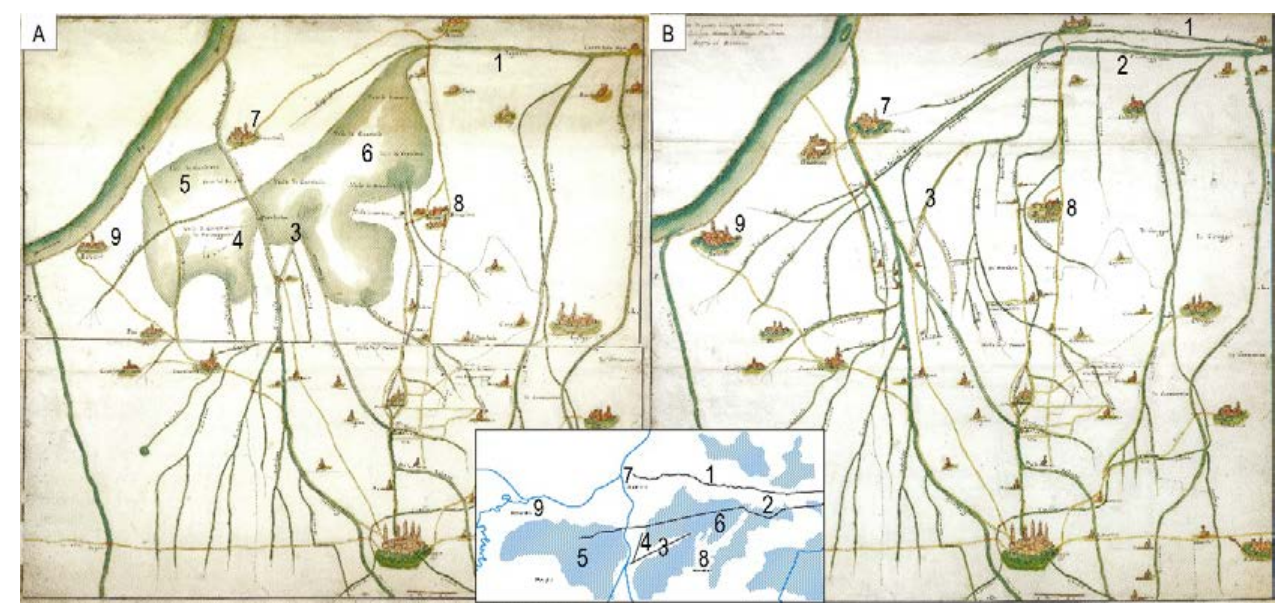

Figure 11. Medieval historical maps (18th-century copies) that show the environmental situation of the study area before (A), (for more details, see also Figure 12) and after (B), (for more details, see also Figure 13) the Renaissance wetland reclamation. The numbers in the schematic box in the center of the image helps to orientate: 1-Tagliata Canal; 2-Parmigiana Canal; 3-Crustulus Vetus; 4-Camporainero area; 5-Valle di Gualtieri backswamp; 6-Valle di Novellara backswamp; 7-Town of Guastalla; 8-Town of Novellara; 9-Town of Gualtieri. (AsMo 52 and 53, XVIIIsec. Modena National Historical Archive_-“Congragazione delle Acque e delle Strade, Reggio e Reggiano") [89]. 
In the study area, the DTM highlights two linear Crostolo ridges, probably the result of anthropogenic activities (Figure 14).

According to Affo' [58], when the practice of breaching river and canal levees was forbidden, the city council of Guastalla allowed the excavation of a channel to divert fluvial sediments from the Crostolo River to the backswamps. The geomorphological linear ridges detected in the DTM are likely to be the result of this large-scale flood management activities. The project of the Guastalla city council likely intended to not spread the fluvial sediments in different areas (land-fill ridges) but to concentrate the muddy river discharge in the wetland to create more arable land. The medieval parchments reported by Affo' [58] gives more details about this channel, stating that it was excavated in an area called "Camporainero" along the "Via di Roncaglio"; both the place names are still used and correspond to the area of the Crostolo straight ridge-oriented NNE (Figure 14). Furthermore, a couple of historical maps (17th century AD copies of Late Medieval originals) help in understanding the geomorphological evolution of the area.

As shown in the historical map (Figures 11A and 12), Camporainero is a portion of the Valle di Gualtieri wetland, and the Crostolo River was artificially diverted into the Po River using the Early Medieval canal called Fossa di Roncaglio. The orientation of the NNE ridge match with the historical description provided by the chronicles. In this map the NNE ridge is not indicated, although it is detected in the DTM: probably the original project consisted of the diversion of the Crostolo River using the Camporainero Canal as well as the Fossa di Roncaglio Canal. The Renaissance project was probably adapted and modified because Camporainero Canal ridge is still recognizable, while the Fossa di Roncaglio has been replaced by the Crostolo River. On the other hand, the linear ridge-oriented NE (Figure 14) has always been identified in the available literature $[48,62]$ as the Crostolo paleochannel active in Roman times and called Crustulus Vetus (or Crostolo Vecchio $\rightarrow$ Old Crostolo). In this study, both geomorphological and historical-archaeological proxies support a new interpretation. First, the ridge leads directly to the Valle Novellara backswamp and it ends in the Roman farmland: here some road and ditches of the centuriation grid are still visible in aerial images [65]. It is not possible that the river watercourse passed here in Roman times. Moreover, along this linear ridge, Roman archaeological finds have never been reported.

Moreover, historical maps dated to the 17th and 18th centuries AD [78] indicate that, along this ridge, a canal called Fossa Alessandrina and was excavated and a church was constructed (the still standing Chiesa di San Bernardino). In Roman times the Crostolo River is likely to have been flanked by artificial levees, and to have flowed into the Po River, north of the medieval Tagliata Canal (Po Morto, see Figure 4). The results of this study support the idea that the Crostolo River in the post-Roman era flowed directly in the Valle di Novellara backswamp developing the fluvial ridge oriented to NE in the DTM. Later, in the 16th century, as recorded in medieval documents, the river was artificially diverted into an area called Camporainero to reclaim wetlands and create new cultivable land for the community of Guastalla. The result is the NNE oriented fluvial ridge detected in the DTM (Figure 14). 


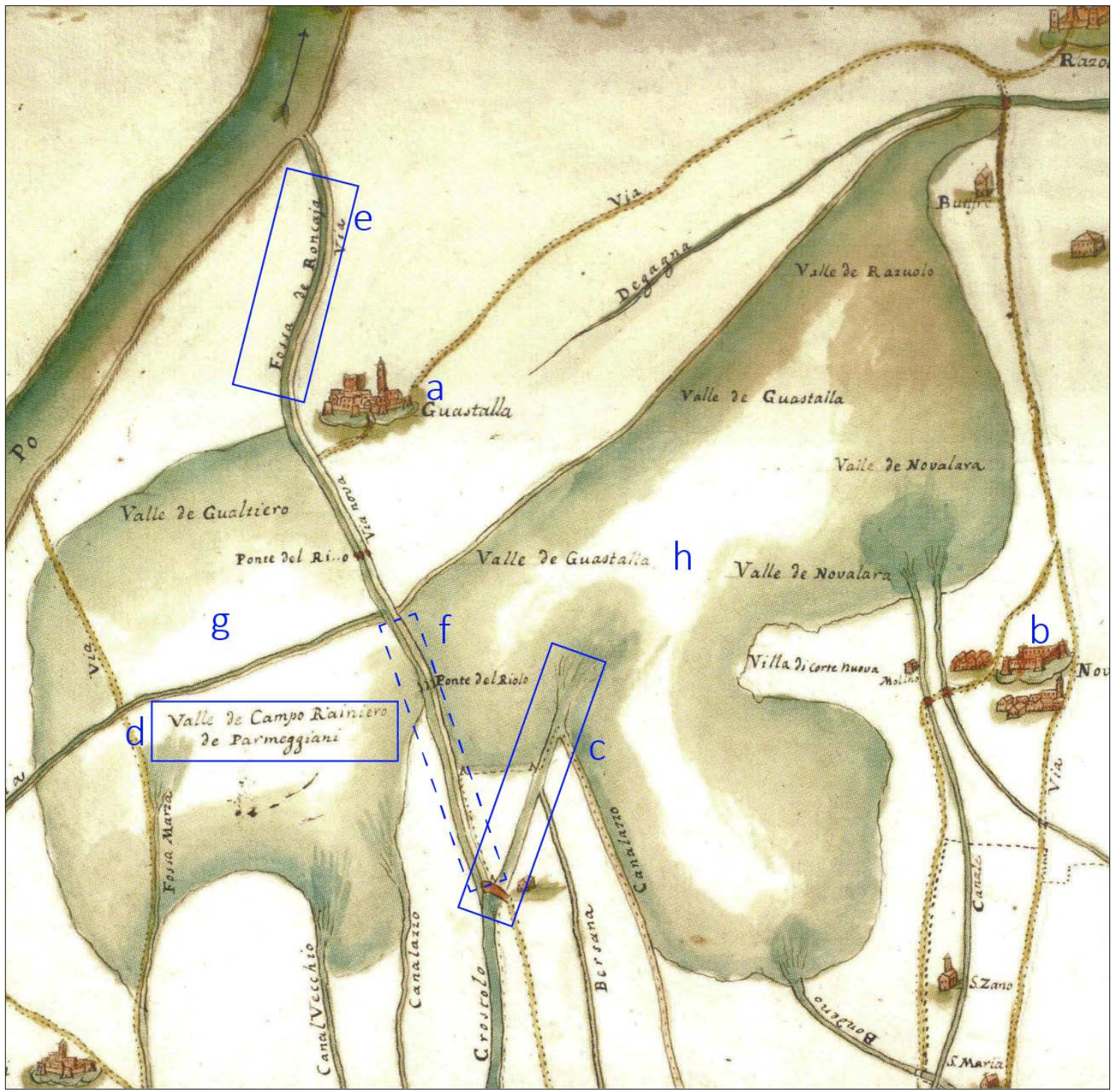

Figure 12. Detail of the medieval historical map that shows the landscape before the Renaissance land reclamation project (Figure 11A). (AsMo 52, XVIIIsec. Modena National Historical Archive“Congragazione delle Acque e delle Strade, Reggio e Reggiano) [89]. This map shows the project of artificially diversion on the Crostolo River from the Valle di Novellara to the Po Plain through the Early Medieval Fossa di Roncaglio Canal. a-Town of Guastalla; b-Town of Novellara; c-the so-called Crustulus Vetus, still active at that time; $\mathrm{d}$-the wetland area called Camporainero; e-Fossa di Roncaglio Canal; $\mathrm{f}$ - the area of the NNE Crostolo ridge, developed to fill the Camporainero area with Crostolo sediments; g-Valle di Gualtieri wetland; h—Valle di Novellara wetland. 


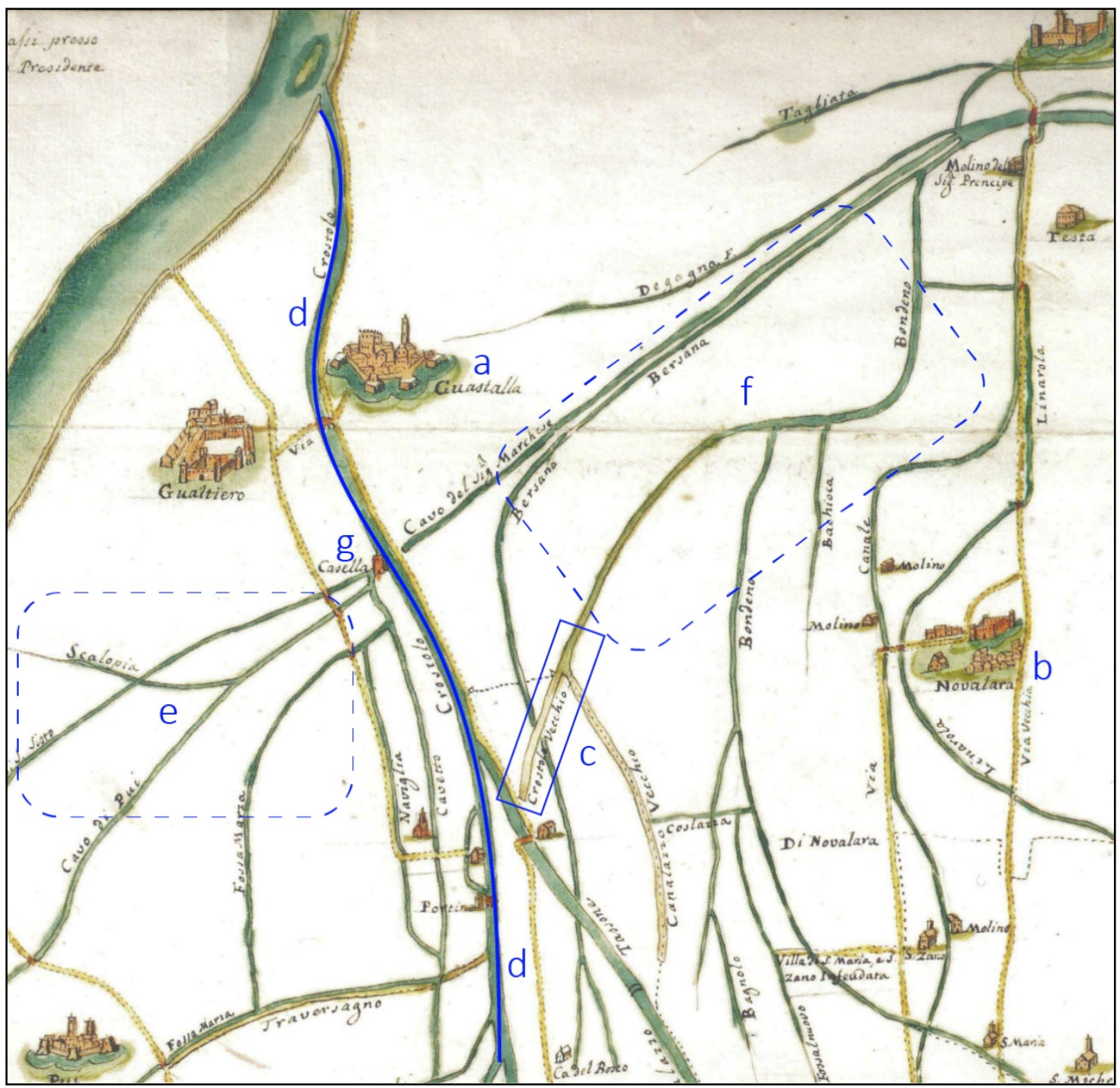

Figure 13. Detail of the medieval historical map which shows the landscape before the Renaissance land reclamation project (Figure 11B). (AsMo 53, XVIIIsec. Modena National Historical Archive“Congragazione delle Acque e delle Strade, Reggio e Reggiano) [89]. This map shows the study area after the Renaissance Bonifica Bentivoglio land reclamation project. a-Town of Guastalla; b-Town of Novellara; c-Crostolo Vecchio or Crustulus Vetus, the medieval Crostolo watercourse that flowed into the Valle di Novellara wetland; $d$-The artificial diversion of the Crostolo River in the Po River; there are no more indications of both Camporainero and Roncaglio; e-Drained area in place of the Valle di Gualtieri wetland; f-Drained area in place of Valle di Novellara wetland; g-Botte Bentivoglio hydraulic device.

The developing of the Camporainero Canal ridge shows similarities to the human management of the crevasses spays reported in the lowlands of the Adige River (Northern Italy) [90]. The first attempts to manage crevasses splays in this area are dated to 12th century AD, and they were finalized at lowering flood hazard and allowing discharge for water mills and navigation through the control of the water intake from the Adige River into the Castagnaro and Malopera Rivers [90].

The Crostolo river was artificially diverted in the Po River only after 1576 during the large-scale land reclamation works called Bonifica Bentivoglio: this project included the excavation of a canal-oriented EW (Parmigiana Canal) to drain the two Valli backswamps and the construction of a hydraulic device that allowed this canal to pass under the Crostolo River. The Bonifica Bentivoglio 
drastically changed the natural medieval landscape by turning the swamps into farmland and constraining the rivers by artificial embankments (Figures 11 and 15).

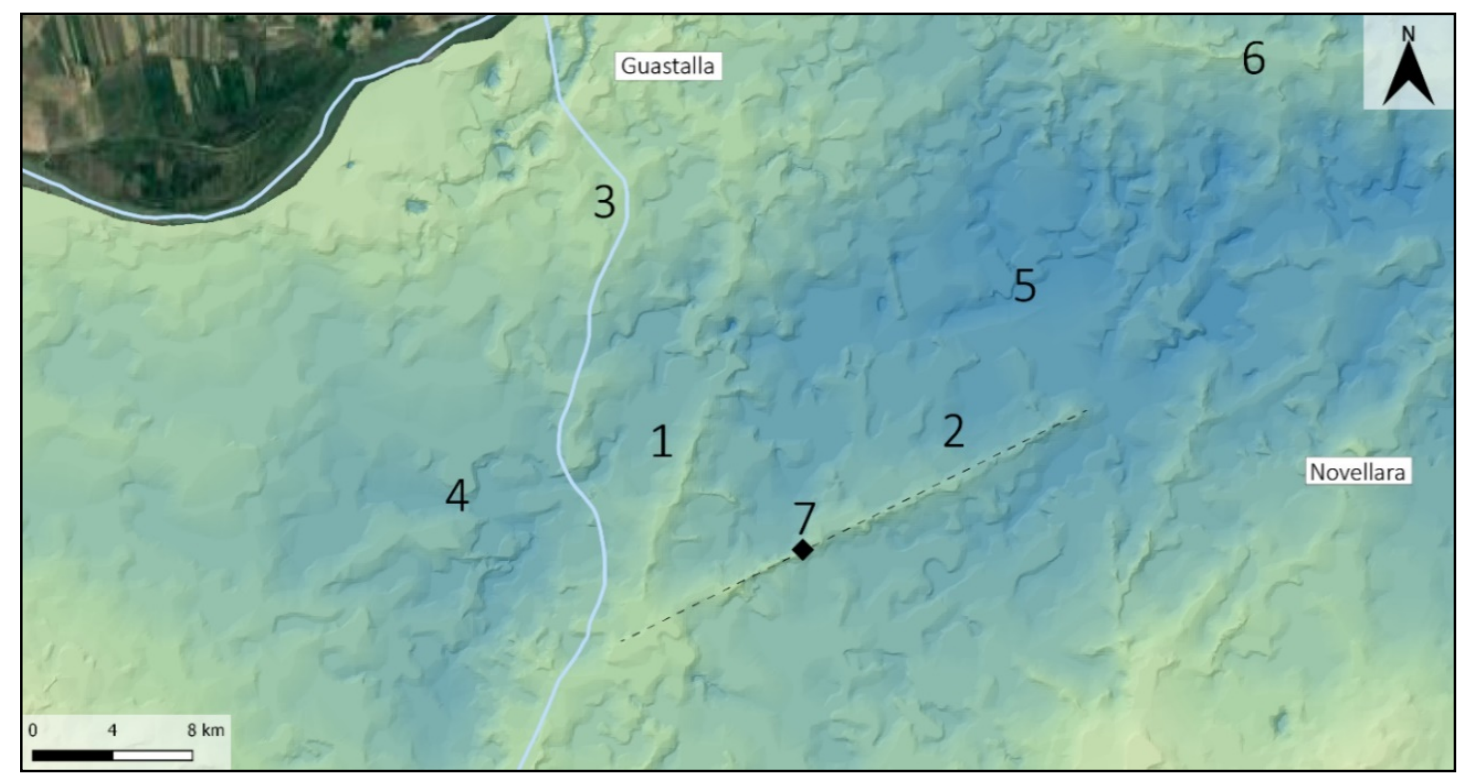

Figure 14. Digital Terrain Model (DTM) of the Crostolo River medieval ridges. 1-NEE Crostolo ridge; 2-NE Crostolo ridge, called Crustulus Vetus; 3-Modern Crostolo River course; 4-Valle di Gualtieri wetland area; 5-Valle di Novellara wetland area; 6-Tagliata Canal ridge; 7-The dashed line indicates the modern Age Fossa Alessandrina Canal, the black square represents the S. Bernardino Church.

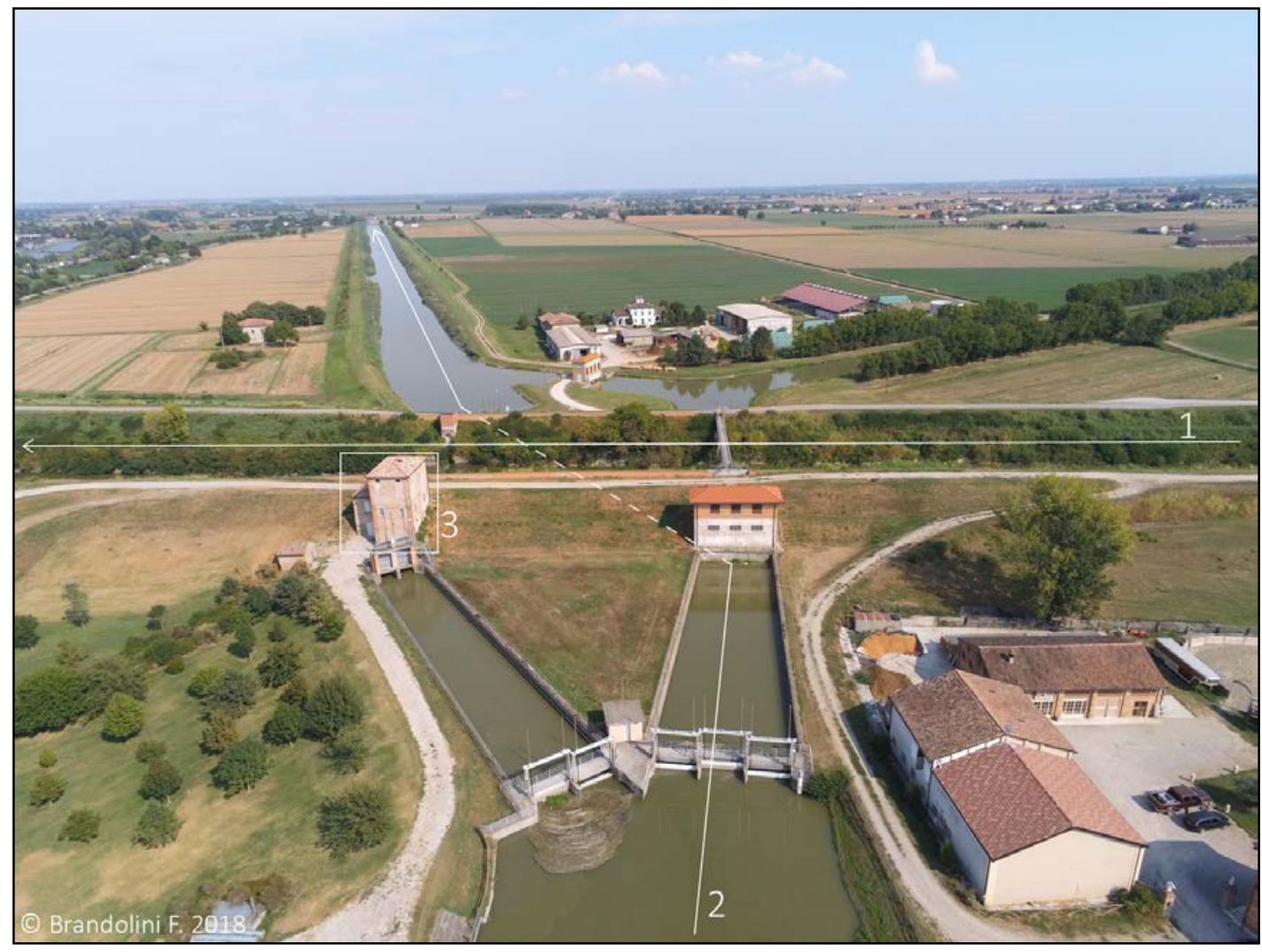

Figure 15. The crossing between the Crostolo River (1) with the Parmigiana Canal (2) in the modern completely drained countryside. The white square highlights the 17th century AD structure of the Botte Bentivoglio hydraulic device (3). 


\section{Conclusions}

This study sheds new light on the evolution of the Central Po Plain landscape in the Late Holocene.

The dynamic climatic conditions that occurred after the collapse of the Western Roman Empire led to a significant change in the well-organized Roman countryside, turning large floodplain areas in swamps. In the Early Medieval Age (6th-9th centuries AD) the natural landscape development seems to not have been impacted any significant human-induced changes. On the contrary, the local communities adapted themselves to the post-Roman palustrine environment settling in positions of higher elevation around the swamps limits and using them for navigation as well as for silvopastoral sustenance practices. In contrast, contemporaneous with the Medieval Climate Anomaly (10th-13th century AD), anthropogenic activities altered the landscape to fulfil the new socio-economical needs.

In the research area, the most evident anthropogenic geomorphological features developed in medieval times is the Tagliata Canal ridge. This canal represents a relevant landscape-modifying agent both for natural (flood events) and anthropogenic (land-fill ridges) causes. The exploitation of fluvial sediment to reclaim wetland areas affected the Crostolo River watercourse, as well. The result of human flood management practices was the development of new cultivable land in place of alluvial wetlands. This human-induced landscape transformation is likely not to have happened abruptly, leaving time for the natural environment to adapt to the new anthropogenic landforms. Richard Hoffmann [15] states that "the ecological concept of sustainability is a dynamic equilibrium between human activities in nature and the ability of the natural system to respond to those activities." According to this definition, medieval flood management represented a more sustainable land reclamation technique than the Renaissance large-scale projects that deeply modified the landscape with channelization and artificial levees, turning the palustrine environment into the modern countryside.

Nevertheless, the medieval flood management activities reported in this study constitute an example of the modern "Room-for-River" strategy [36,37]. Indeed, the primary purpose of the medieval practices was to create new arable land, but at the same time, the artificial diversion of fluvial sediments enables the control of floodwaters avoiding the risk of inundation, for example, in urbanized areas or productive farmland. Similar practices have been reported in Northeast Italy [90] were the medieval human management of crevasses splays aimed to control the Adige River discharge to reduce the flood hazard. Understanding the past anthropogenic effect on the landscape is essential for its future sustainable management [91], especially in the Central Po Plain, where the debate around future sustainable solutions to reduce flood hazards is ongoing [3] and the continued raising of embankments is not environmentally sustainable [2].

Author Contributions: Conceptualization, F.B. and M.C.; Data curation, F.B.; Formal analysis, F.B.; Funding acquisition, M.C.; Investigation, F.B.; Methodology, F.B. and M.C.; Project administration, M.C.; Resources, M.C.; Supervision, M.C.; Validation, F.B. and M.C.; Writing—original draft, F.B.; Writing—review and editing, F.B. and M.C.

Funding: This research was carried out in the framework of the SUCCESSO-TERRA Project funded by PRIN-MIUR (project PRIN20158KBLNB, Principal Investigator: M. Cremaschi).

Acknowledgments: The authors thank Nicki Whitehouse (University of Plymouth) and Benjamin Gearey (University College Cork) for their suggestions about a possible comparison between the land-fill ridges and warping practices. Also, the authors thank also to Rachel Kulick (University of Toronto) that reviewed the English of the manuscript. Finally, the authors are grateful to the anonymous reviewers for their constructive criticism and comments.

Conflicts of Interest: The authors declare no conflict of interest.

\section{References}

1. Merz, B.; Hall, J.; Disse, M.; Schumann, A. Fluvial flood risk management in a changing world. Nat. Hazards Earth Syst. Sci. 2010, 10, 509-527. [CrossRef]

2. Castellarin, A.; Di Baldassarre, G.; Brath, A. Floodplain Management Strategies for Flood Attenuation in the River Po. River Res. Appl. 2011, 27, 1037-1047. [CrossRef] 
3. Domeneghetti, A.; Carisi, F.; Castellarin, A.; Brath, A. Evolution of flood risk over large areas: Quantitative assessment for the Po river. J. Hydrol. 2015, 527, 809-823. [CrossRef]

4. Dankers, R.; Feyen, L. Flood hazard in Europe in an ensemble of regional climate scenarios. J. Geophys. Res. 2009, 114, 1-16. [CrossRef]

5. Akter, T.; Quevauviller, P.; Eisenreich, S.J.; Vaes, G. Impacts of climate and land use changes on flood risk management for the Schijn River, Belgium. Environ. Sci. Policy 2018, 89, 163-175. [CrossRef]

6. Feulner, F. The Late Mesolithic Bark Floor of the Wetland Site of Rüde 2, Schleswig-Holstein, Germany. J. Wetl. Archaeol. 2011, 11, 109-119. [CrossRef]

7. Ollivier, V.; Fontugne, M.; Hamon, C.; Decaix, A.; Hattè, C.; Jalabadz, M. Neolithic water management andfl ooding in the Lesser Caucasus (Georgia). Quat. Sci. Rev. 2018, 197, 267-287. [CrossRef]

8. Hausmann, J.; Zielhofer, C.; Werther, L.; Berg-Hobohm, S.; Dietricha, P.; Heymann, R.; Werban, U. Direct push sensing in wetland (geo)archaeology: High-resolution reconstruction of buried canal structures (Fossa Carolina, Germany). Quat. Int. 2018, 473 Pt A, 21-36. [CrossRef]

9. Kirchner, A.; Zielhofer, C.; Werther, L.; Schneider, M.; Linzen, S.; Wilken, D.; Wunderlich, T.; Rabbel, W.; Meyer, C.; Schmidt, J.; et al. A multidisciplinary approach in wetland geoarchaeology: Survey of the missing southern canal connection of the Fossa Carolina (SW Germany). Quat. Int. 2018, 473, 3-20. [CrossRef]

10. Büntgen, U.; Tegel, W.; Nicolussi, K.; Mc Cormick, M.; Frank, D.; Trouet, V.; O Kaplan, J.; Herzig, F.; Heussner, K.U.; Wanner, H.; et al. 2500 Years of European Climate Variability and Human Susceptibility. Science 2011, 331, 578-582. [CrossRef] [PubMed]

11. Christiansen, B.; Ljungqvist, F.C. The extra-tropical Northern Hemisphere temperature in the last two millennia: Reconstructions of low-frequency variability. Clim. Past 2012, 8, 765-786. [CrossRef]

12. Mensing, S.; Tunno, I.; Sagnotti, L.; Florindo, F.; Noble, P.; Archer, C.; Zimmerman, S.; Pavón-Carrasco, F.J.; Cifani, G.; Passigli, S.; et al. 2700 years of Mediterranean environmental change in central Italy: Asynthesis of sedimentary and cultural records to interpret past impacts of climate on society. Quat. Sci. Rev. 2015, 116, 72-94. [CrossRef]

13. Rippon, S. Adaptation to a changing environment: The response of marshland communities to the late medieval 'crisis'. J. Wetl. Archaeol. 2001, 1, 15-39. [CrossRef]

14. Malanima, P. Urbanisation and the Italian economy during the last millennium. Eur. Rev. Econ. Hist. 2005, 9, 99-102. [CrossRef]

15. Hoffmann, R.C. An Environmental History of Medieval Europe; Cambridge University Press: Cambridge, UK, 2014; ISBN 9781139050937.

16. Mensing, S.; Tunno, I.; Cifani, G.; Passigli, S.; Noble, P.; Archer, C.; Piovesan, G. Human and climatically induced environmental change in the Mediterranean during the Medieval Climate Anomaly and Little Ice Age: A case from central Italy. Anthropocene 2016, 15, 49-59. [CrossRef]

17. Curtis, D.R.; Campopiano, M. Medieval land reclamation and the creation of new societies: Comparing Holland and the Po Valley, c.800-c.1500. J. Hist. Geogr. 2014, 44, 93-108. [CrossRef]

18. Groenewoudt, B.; Van Doesburg, D. Peat People. On the Function and Context of Medieval Artificial Platforms in a Coastal Wetland, Eelder- and Peizermaden, The Netherlands. J. Wetl. Archaeol. 2018, 18, 77-96. [CrossRef]

19. Willemsen, J.; van't Veer, R.; van Geel, B. Environmental change during the medieval reclamation of the raised-bog area Waterland (The Netherlands): A palaeophytosociological approach. Rev. Palaeobot. Palynol. 1996, 94, 75-86. [CrossRef]

20. Pals, J.P.; van Dierendonck, M.C. Between flax and fabric: Cultivation and processing of flax in a mediaeval peat reclamation settlement near midwoud (Prov. Noord Holland). J. Archaeol. Sci. 1988, 15, 237-251. [CrossRef]

21. Gardiner, M.; Hartwell, B. Landscapes of Failure: The Archaeology of Flooded Wetlands at Titchwell and Thornham (Norfolk), and Broomhill (East Sussex). J. Wetl. Archaeol. 2006, 6, 137-160. [CrossRef]

22. Hadler, H.; Vött, A.; Newig, J.; Emde, K.; Finkler, C.; Fischer, P.; Willershäuser, T. Geoarchaeological evidence of marshland destruction in the area of Rungholt, present-day Wadden Sea around Hallig Südfall (North Frisia, Germany), by the Grote Mandrenke in 1362 AD. Quat. Int. 2018, 473, 37-54. [CrossRef]

23. Brühl, C. (Ed.) Codice Diplomatico Longobardo; III, no. 41; Istituto Storico Italiano per il Medio Evo: Rome, Italy, 1973. 
24. Squatriti, P. Water and Society in Early Medieval Italy AD 400-1000; Cambridge University Press: Cambridge, UK, 1998; ISBN 0521522064.

25. Fumagalli, V. L'uomo e L'ambiente nel Medioevo; Editori Laterza: Roma, Italy, 1999; ISBN 884206954X.

26. Fumagalli, V. Città e Campagna nell'Italia Medievale; Pàtron Editore: Bologna, Italy, 1985; ISBN 978-8855519328.

27. Magnusson, R. Water Technology in the Middle Ages: Cities, Monasteries, and Waterworks after the Roman Empire; JHU Press: Baltimore, MD, USA, 2001; ISBN 080186626X.

28. Ambrosini, C.; De Marchi, P.M. (Eds.) Uomini e Acque a San Benedetto Po-Il Governo del Territorio tra Passato e Futuro, in Atti del Convegno (Mantova-San Benedetto Po, 10-12 maggio 2007); All'Insegna del Giglio: Firenze, Italy, 2010; ISBN 9788878144224.

29. Hodges, R. Dark Age Economics: A New Audit; Bloomsbury Academic: Bristol, UK, 2012; ISBN 9780715636794.

30. Settia, A.A. Proteggere e Dominare, Fortificazioni e Popolamento nell'Italia Medievale; Viella Libreria Editrice: Roma, Italy, 1999; ISBN 9788883346071.

31. Settia, A.A. Castelli e Villaggi nell'Italia Padana; Liguori Editore: Napoli, Italy, 1984; ISBN 8820712113.

32. Wikimedia Commons. Available online: https://commons.wikimedia.org/wiki/File:Paludes1570.jpg (accessed on 13 March 2018).

33. Gabbi, B. La Bonifica Bentivoglio-Enza. Antologia Documentaria Sulle Acque; Reggio Emilia: Parma, Italy, 2001; ISBN 881031299.

34. Saltini, A. Dove L'uomo Separò la Terra Dalle Acque: Storia Delle Bonifiche dell'Emilia-Romagna; Reggio Emilia: Parma, Italy, 2005; ISBN 8881034336.

35. Tobin, G.A. The Levee Love Affair: A Stormy Relationship. J. Am. Water Resour. Assoc. 1995, 31, $359-367$. [CrossRef]

36. Vis, M.; Klijn, F.; De Bruijn, K.M.; Van Buuren, M. Resilience strategies for flood risk management in The Netherlands. Int. J. River Basin Manag. 2003, 1, 33-40. [CrossRef]

37. Silva, W.; Klijn, F.; Dijkman, J. Room for the Rhine Branches in The Nederlands. In What the Research Has Taught Us; Delft Hydaulics Report R3294; RIZA Report: Delft, The Netherlands, 2001; p. 31.

38. Bottazzi, G. Gli agri centuriati di Brixellum e di Tannetum. In L'Emilia in età Romana; Ricerche di Topografia Antica: Modena, Italy, 1987; pp. 149-191.

39. Cremaschi, M.; Pizzi, C.; Valsecchi, V. Water management and land use in the terramare and a possible climatic co-factor in their abandonment: The case study of the terramara of Poviglio Santa Rosa (northern Italy). Quat. Int. 2006, 151, 87-98. [CrossRef]

40. Mele, M.; Cremaschi, M.; Giudici, M.; Lozej, A.; Pizzi, C.; Bassi, A. The Terramare and the surrounding hydraulic structures: A geophysical survey of the Santa Rosa site at Poviglio (Bronze Age, northern Italy). J. Archaeol. Sci. 2013, 40, 4648-4662. [CrossRef]

41. Cremaschi, M.; Nicosia, C. Sub-Boreal Aggradation along the Apennines margin of the Central Po plain: Geomorphological and geoarchaeological aspects. Gèomorphologie 2012, 2, 156-174. [CrossRef]

42. Cremaschi, M.; Mercuri, A.M.; Torri, P.; Florenzano, A.; Pizzi, C.; Marchesini, M.; Zerboni, A. Climate change versus land management in the Po Plain (Northern Italy) during the Bronze Age: New insights from the VP/VG sequence of the Terramara Santa Rosa di Poviglio. Quat. Sci. Rev. 2016, 136, 153-172. [CrossRef]

43. Ravazzi, C.; Marchetti, M.; Zanon, M.; Perego, R.; Quirino, T.; Deaddis, M.; De Amicis, M.; Margaritora, D. Lake evolution and landscape history in the lower Mincio River valley, unravelling drainage changes in the central Po Plain (N-Italy) since the Bronze Age. Quat. Int. 2013, 288, 195-205. [CrossRef]

44. Mercuri, A.M.; Montecchi, M.C.; Pellacani, G.; Florenzano, A.; Rattighieri, E.; Cardarelli, A. Environment, human impact and the role of trees on the Po plain during the Middle and Recent Bronze Age: Pollen evidence from the local influence of the terramare of Baggiovara and Casinalbo. Rev. Palaeobot. Palynol. 2015, 218, 231-249. [CrossRef]

45. Marchetti, M. Environmental changes in the central Po Plain (northern Italy) due to fluvial modifications and anthropogenic activities. Geomorphology 2002, 44, 361-373. [CrossRef]

46. Charlton, R. Fundamentals of Fluvial Geomorphology; Routledge: New York, NY, USA, 2007; ISBN 978-0415334549.

47. Castiglioni, G.B.; Ajassa, R.; Baroni, C.; Biancotti, A.; Bondesan, A.; Bondesan, M. Carta Geomorfologica Della Pianura Padana. 3 Fogli Alla Scala 1:250.000; IRIS: Firenze, Italy, 1997.

48. Cremaschi, M.; Bernabò Brea, M.; Tirabassi, J.; Dall'Aglio, P.L.; Baricchi, W.; Marchesini, A.; Nepoti, S. L'evoluzione del settore centromeridionale della valle padana, durante l'età del bronzo, l'età romana e l'età altomedievale, geomorfologia ed insediamenti. Padusa 1980, 16, 5-25. 
49. Cremaschi, M.; Storchi, P.; Perego, A. Geoarchaeology in urban context: The town of Reggio Emilia and river dynamics during the last two millennia in Northern Italy. Geoarchaeology 2018, 33, 52-66. [CrossRef]

50. Bernabò Brea, M.; Cremaschi, M. Il Villaggio Piccolo Della Terramara di Santa Rosa di Poviglio: Scavi 1987-1992; IRIS: Firenze, Italy, 2004; ISBN 8860450144.

51. Bottazzi, G.; Bronzoni, L.; Mutti, A. Carta Archeologica del Comune di Poviglio 1986-1989; IRIS: Poviglio, Italy, 1995.

52. Settis, S.; Pasquinucci, M. Misurare La Terra: Centuriazione e Coloni nel Mondo Romano; Franco Cosimo Panini: Modena, Italy, 1984; ISBN 88-7686-014-2.

53. Lamb, H.H. Climate, History and the Modern World; Routledge: London, UK, 1995; ISBN 9780415127356.

54. Montanari, M. L'alimentazione Contadina Nell'alto Medioevo; Liguori Publications: Napoli, Italy, 1983; ISBN 8820707748.

55. Calzolari, M. La navigazione interna in Emilia Romagna tra VIII e XIII secolo. In Vie del Commercio in Emilia Romagna Marche; Alfieri, N., Ed.; Silvana: Cinisello Balsamo, Italy, 1991; pp. 115-124. ISBN 9788836603053.

56. Racine, P. Poteri medievali e percorsi fluviali nell'Italia padana. Quaderni Storici 1986, 61, 9-32.

57. Brandolini, F.; Trombino, L.; Sibilia, E.; Cremaschi, M. Micromorphology and site formation processes in the Castrum Popilii Medieval Motte (N Italy). J. Archaeol. Sci. Rep. 2018, 20, 18-32. [CrossRef]

58. Affò, I. Istoria di Guastalla; Costa: Parma, Italy, 1786.

59. Tiraboschi, G. Dizionario Topografico Degli Stati Estensi; tipogr. Camerale: Modena, Italy, 1824.

60. Cantarelli, C. Cronaca di fra Salimbene Parmigiano Dell'ordine dei Minori; Luigi Battei: Parma, Italy, 1882.

61. Pasquali, G. L'azienda curtense e l'economia dei secoli VI-XI. In Uomini e Campagne nell'Italia Medievale; Cortonesi, A., Ed.; Laterza: Roma, Italy, 2003; pp. 19-20. ISBN 9788842066682.

62. Mancassola, N. Uomini e acque nella pianura reggiana durante il Medioevo (Secoli IX-XIV). In Acque e Territorio nel Veneto Medievale; Canzian, D., Simonetti, R., Eds.; Viella: Roma, Italy, 2012; pp. 115-132. ISBN 9788867281473.

63. Fumagalli, V. L'alba del Medioevo; L’Edizione Del Mulino: Bologna, Italy, 2004; ISBN 978-88-15-25387-3.

64. Rao, R. I Paesaggi dell'Italia Medievale; Routledge: Roma, Italy, 2016; ISBN 8843077759.

65. Brandolini, F.; Cremaschi, M. Valli-Paludi nel Medioevo: Il rapporto tra uomo e acque nella Bassa Pianura Reggiana. Le bonifiche "laiche" per colmata. In VIII Congresso Nazionale di Archeologia Medievale. Pré-Tirages (Matera, 12-15 Settembre 2018); Sogliani, F., Gargiulo, B., Annunziata, E., Vitale, V., Eds.; All'Insegna del Giglio: Firenze, Italy, 2018; Volume 2, pp. 72-78. ISBN 9788878148673.

66. Mori, A. Le Antiche Bonifiche Della Bassa Reggiana; La Bodoniana: Parma, Italy, 1923.

67. Castaldini, D. Evoluzione della rete idrografica centropadana in epoca protostorica e storica. In Atti del Convegno Nazionale di Studi-Insediamenti e Viabilità Nell'alto Ferrarese Dall'età Romana al Medioevo, Cento 1987; ITA: Ferrara, Italy, 1989; pp. 115-134.

68. Castiglioni, G.B.; Pellegrini, G.B. Note Illustrative della Carta Geomorfologica Della Pianura Padana; Supplementi di Geografia Fisica e Dinamica Quaternaria; Comitato Glaciologico Italiano: Torino, Italy, 2001; Volume 4, pp. 328-421.

69. Geoportale Nazionale. Available online: http:/ / www.pcn.minambiente.it/mattm/ (accessed on 24 February 2018).

70. Geoportale Emilia Romagna Region. Available online: http://geoportale.regione.emilia-romagna.it/it (accessed on 13 March 2018).

71. Degani, M. Carta Archeologica Della Carta d'Italia al 1:100.000; Foglio 74 (Città e Provincia di Reggio Emilia); LS Olschki: Firenze, Italy, 1974.

72. Baricchi, W. (Ed.) Insediamento Storico e Beni Culturali Bassa Pianura Reggiana: Comuni di Boretto, Brescello, Fabbrico, Gualtieri, Guastalla, Luzzara, Novellara, Poviglio, Reggiolo, Rolo; Reggio Emilia: Parma, Italy, 1989.

73. Castelli dell'Emilia-Romagna: Censimento e Schedatura. Available online: http://geo.regione.emiliaromagna.it/schede/castelli/index.jsp (accessed on 18 April 2018).

74. Affò, I. Storia di Parma; Carmignani: Parma, Italy, 1792.

75. Drei, G. Le Carte Degli Archivi Parmensi dei Secoli X-XI; Reggio Emilia: Parma, Italy, 1924.

76. Torelli, P. Le Carte Degli Archivi Reggiani: Fino al 1050; Reggio Emilia: Parma, Italy, 1924.

77. Torelli, P.; Gatta, F.S. Le Carte degli Archivi Reggiani 1051-1060; Reggio Emilia: Parma, Italy, 1938.

78. Angiolini, E.; Torresan, S. Archivio Storico del Comune di Novellara; Inventario; Comune di Novellara: Novellara, Italy, 2015. 
79. Larsen, L.; Vinther, B.; Briffa, K.; Melvin, T.; Clausen, H.; Jones, P.; Siggaard-andersen, M.; Hammer, C.; Eronen, M.; Grudd, H.; et al. New ice core evidence for a volcanic cause of the A.D. 536 dust veil. Geophys. Res. Lett. 2008, 35, L04708. [CrossRef]

80. Squatriti, P. The Floods of 589 and Climate Change at the Beginning of the Middle Ages: An Italian Microhistory. Speculum 2010, 85, 799-826. [CrossRef] [PubMed]

81. Macphail, R.I.; Goldberg, P. Practical and Theoretical Geoarchaeology; Blackwell Publishing: Oxford, UK, 2006; ISBN 0632060441.

82. Iannacci, L.; Mezzetti, M.; Modesti, M.; Zuffrano, A. Chartae Latinae Antiquiores. Facsimile-Edition of the Latin Charters. Ninth Century. Part XCI-Italy LXIII, 2nd Series; Reggio Emilia: Firenze, Italy; Urs Graf Verlag: Zurich, Switzerland, 2012; ISBN 9783859512337.

83. Moreno, D. Miglioramenti agrari sullo spartiacque Trebbia-Aveto. Tracce di "colmate di monte" di età post-medievale. In La Natura Della Montagna; Cevasco, R., Ed.; Gallucci: Setri Levante, Italy, 2013; pp. 424-439. ISBN 88-97264-22-0.

84. Moreno, D. Improving land with water: Evidence of historical "colmate di monte" in the Trebbia-Aveto watershed. In Proceedings of 2nd Workshop on Environmental History and Archaeology; All'Insegna del Giglio: Montebruno, Italy, 2002.

85. Cevasco, A.; Cevasco, R. "Montagne che libbiano" e zone umide colmate? Il "lago" di Torrio (Val d'Aveto, Ferriere, Pc). In La Natura Della Montagna; Cevasco, R., Ed.; Gallucci: Sestri Levante, Italy, 2013; pp. 440-448. ISBN 88-97264-22-0.

86. Lillie, M.; Weir, D. Alluvium and warping in the Humberhead Levels: The identification of factors obscuring palaeo land surfaces and the archaeological record. In Wetland Heritage of the Humberhead Levels; Van de Noort, R., Ellis, S., Eds.; University of Hull: East Riding of Yorkshire, UK, 1997; pp. 191-218. ISBN 0859581926.

87. Mansell, L.; Whitehouse, N.; Gearey, B.; Barratt, P.; Roe, H. Holocene floodplain palaeoecology of the Humberhead Levels; implications for regional wetland development. Quat. Int. 2014, 341, 91-109. [CrossRef]

88. Lillie, M.; Weir, D. Alluvium and warping in the lower Trent valley. In Wetland Heritage of the Ancholme and Lower Trent Valleys_-An Archaeological Survey; Van de Noort, R., Ellis, S., Eds.; University of Hull: East Riding of Yorkshire, UK, 1998; pp. 103-122. ISBN 0859581934.

89. Adani, G.; Badini, G.; Baricchi, W.; Pellegrini, M.; Pozzi, F.M.; Spaggiari, A. Vie D'acqua nei Ducati Estensi; Cassa di Risparmio di Reggio Emilia, Amilcare Pizzi Editore: Cinisello Balsamo/Milano, Italy, 1990; ISBN 9788837055455.

90. Mozzi, P.; Piovan, S.; Corrò, E. Long-term drivers and impacts of abrupt river changes in managed lowlands of the Adige river and northern PO delta (Northern Italy). Quat. Int. 2018, in press. [CrossRef]

91. Merz, B.; Aerts, J.; Arnbjerg-Nielsen, K.; Baldi, M.; Becker, A.; Bichet, A.; Blöschl, G.; Bouwer, L.M.; Brauer, A.; Cioffi, F; et al. Floods and climate: Emerging perspectives for flood risk assessment and management. Nat. Hazards Earth Syst. Sci. 2014, 14, 1921-1942. [CrossRef]

(C) 2018 by the authors. Licensee MDPI, Basel, Switzerland. This article is an open access article distributed under the terms and conditions of the Creative Commons Attribution (CC BY) license (http://creativecommons.org/licenses/by/4.0/). 